\title{
DETERMINAN MINAT PENGGUNAAN E-SPT
}

\author{
Marta Ramadani \\ Novrida Qudsi Lutfillah* \\ Universitas Wijaya Putra, Jalan Raya Benowo No. 1-3, Surabaya \\ *vridaoayu@gmail.com
}

\section{A R T I C L E I N F O}

Article history:

Received September 1, 2019

Revised Desember 20, 2019

Accepted January 7, 2020

Key words:

Tax, Tax Payer, System, E-SPT

DOI:

10.33508/jako.v12i1.2129

\begin{abstract}
A B S T R A C T
This study aims to examine and analyze the influence of perceptions of usability, trust and computer self efficacy on the interest in using e-SPT in Surabaya. Respondents in this study were 90. Samples were taken using quota sampling with non probability sampling techniques.Data analysis was performed using statistics with SPSS tools. Based on the results of data analysis using the t test it is known that partially the perception of usability, trust and computer self efficacy has a positive and significant influence on the interest in using e-SPT. While based on the results of data analysis using the F test it is known that simultaneously the perception of usability, trust and computer self efficacy has a positive and significant effect on the interest in using e-SPT.
\end{abstract}

\begin{abstract}
A B S T R A K
Penelitian ini bertujuan untuk menguji dan menganalisis pengaruh persepsi kegunaan, kepercayaan dan computer self efficacy terhadap minat penggunaan eSPT di Surabaya. Responden dalam penelitian ini sebanyak 90. Sampel diambil dengan menggunakan sampling kuota dengan teknik non probability sampling. Analisis data dilakukan dengan menggunakan statistik dengan alat bantu SPSS. Berdasarkan hasil analisis data dengan menggunakan uji $t$ diketahui bahwa secara parsial persepsi kegunaan, kepercayaan dan computer self efficacy memiliki pengaruh positif dan signifikan terhadap terhadap minat penggunaan e-SPT. Sedangkan berdasarkan hasil analisis data dengan menggunakan uji F diketahui bahwa secara simultan persepsi kegunaan, kepercayaan dan computer self efficacy berpengaruh positif dan signifikan terhadap minat penggunaan e-SPT.
\end{abstract}

\section{PENDAHULUAN}

Dalam mengantisipasi perkembangan teknologi, Direktorat Jendral Pajak (DJP) melakukan pembaharuan-pembaharuan dalam sistem perpajakan.Pembaharuan dalam sistem perpajakan ini ditandai dengan penerapan teknologi informasi terkini dalam pelayanan perpajakan.Peningkatan pelayanan perpajakan ini terlihat dengan dikembangkannya modernisasi administrasi perpajakan.Salah satu bentuk modernisasi perpajakan dalam hal penggunaan teknologi informasi administrasi perpajakan adalah penerapan media elektronik e-sistem, misalnya e-SPT.

Pada tahun 2018, laporan e-SPT naik 14\% dibandingkan periode yang sama tahun 2017, maka minat wajib pajak dalam menggunakan eSPT semakin tinggi di tahun 2018, sedangkan penyampaian SPT manual turun 12\% (Saksama, 2018). Berdasarkan data tersebut, diketahui bahwa wajib pajak mulai meminati dan menggunakan aplikasi e-SPT dalam melaporkan pajak.
Rachmawati (2018) mengungkapkan jumlah wajib pajak yang sudah melaporkan SPT pada tahun 2018 sekitar 81.000 dari total wajib pajak yang lapor SPT yakni 340.000 di 13 Kantor Pajak Pratama (KPP) se-Surabaya.Kesiapan teknologi pada dasarnya dipengaruhi oleh individu itu sendiri, apakah dari dalam diri individu siap menerima teknologi (Risky, 2015), khususnya dalam hal ini eSPT.

Persepsi kegunaan yang diungkapkan oleh Novindra dan Rasmini (2017) adalah suatu ukuran dimana pengguna yakin dengan menggunakan teknologi bisa mendatangkan manfaat bagi pekerjaannya. Selain itu, ada juga faktor internal yang memengaruhi minat penggunaan aplikasi e-SPT, yaitu kepercayaan. Percaya terhadap sesuatu dapat mememengaruhi orang untuk menerapkan, menggunakan dan menjalankannya (Chandra, 2016).

Faktor lainnya yaitu, computer self efficacy. Computer self efficacy menjadi salah satu faktor yang ada 
dalam diri pengguna atau wajib pajak. Computer self efficacy terhadap aplikasi e-SPT adalah wajib pajak yang mempunyai keyakinan terhadap kemampuan yang ada pada dirinya untuk pelaporan pajak menggunakan e-SPT (Novindra dan Rasmini, 2017).

Penelitian ini mengacu pada penelitian sebelumnya yang dilakukan oleh Chandra (2016) yang membahas tentang pengaruh kemudahan penggunaan, kepercayaan dan computer self efficacy terhadap minat penggunaan e-SPT dalam pelaporan pajak. Penilitian ini juga dilatarbelakangi oleh penelitian Novindra dan Rasmini (2017) yang membahas tentang pengaruh kemudahan penggunaan, persepsi kegunaan dan computer self efficacy pada minat penggunaan e-SPT.

Pembaharuan yang dilakukan dalam penelitian ini sehingga layak untuk diteliti, yaitu dengan pengembangan variabel independen dari penelitian Novindra dan Rasmini (2017) dan penelitian Chandra (2016) yang dijadikan sebagai dasar penelitian ini.Persamaan penelitian Novindra dan Rasmini (2017) dengan penelitian ini adalah variabel independen $(\mathrm{x})$ persepsi kegunaan dan computer self efficacy, serta variabel dependen (y) minat penggunaan e-SPT. Dan perbedaannya ada pada variabel independen $(x)$ kemudahan penggunaan diganti dengan variabel kepercayaan yang diambil dari penelitian Chandra (2016).Sedangkan persamaan penelitian Chandra (2016) dengan penelitian ini adalah variabel independen $(x)$ kepercayaan dan computer self efficacy, serta variabel dependen (y) minat penggunaan e-SPT. Dan perbedaannya ada pada varibel independen $(\mathrm{x})$ kemudahan penggunaan yang diganti dengan variabel persepsi kegunaan yang diambil dari penelitian Novindra dan Rasmini (2017).Berdasarkan hal tersebut, maka penulis tertarik untuk mengambil penelitian dengan judul "Determinan Minat Penggunaan ESPT".

Berdasarkan uraian latar belakang di atas, maka penulis dapat merumuskan masalah sebagai berikut : (1) Apakah persepsi kegunaan berpengaruh terhadap minat penggunaan e-SPT? (2) Apakah kepercayaan berpengaruh terhadap minat penggunaan e-SPT? (3) Apakah computer self efficacyberpengaruh terhadap minat penggunaan e-SPT? Tujuan penelitian untuk menganalisis dan menguji determinan minat penggunaan e-SPT.

\section{KAJIAN LITERATUR DAN PENGEMBANGAN HIPOTESIS}

Teori TAM

Technology Acceptance Model (TAM) adalah sua- tu model untuk memprediksi dan menjelaskan bagaimana pengguna teknologi menerima dan menggunakan teknologi tersebut dalam pekerjaan individual pengguna (Desmayanti, 2012). Sedangkan teori TAM yang dikemukakan oleh Novindra dan Rasmini (2017) menjelaskan tentang bagaimana pengguna teknologi informasi mengembangkan teori psikologis berdasarkan pada keinginan, kepercayaan, hubungan perilaku pengguna dan sikap. Teori TAM menjadi salah satu cara yang dapat digunakan untuk mengetahui minat penggunaan e-SPT melalui faktor tingkat kemanfaatan suatu teknologi informasi yang dirasakan oleh pengguna.

Novindra dan Rasmini (2017) menjelaskan tentang Teori TAM memiliki konstruk yang terdiri dari: Pertama, persepsi kemudahan penggunaan, dijelaskan bagaimana seseorang percaya terhadap suatu teknologi. Kedua, persepsi kegunaan, dijelaskan sebagai kepercayaan seseorang terhadap suatu teknologi. Ketiga, sikap terhadap penggunaan teknologi, dijelaskan bagaimana seseorang tertarik untuk menggunakan suatu teknologi dalam pekerjaannya. Keempat, minat perilaku menggunakan teknologi, dijelaskan bagaimana seseorang memiliki keinginan untuk menggunakan dan menjalankan suatu teknologi. Kelima, penggunaan teknologi, hal ini dapat dilihat dari sejauh mana seseorang membutuhkan waktu untuk berinteraksi dengan teknologi.

\section{Persepsi Kegunaan}

Persepsi menurut Situmorang (2016) adalah proses seseorang dalam memberikan pendapat, kesan dan penilaian terhadap sesuatu berdasarkan informasi yang diterimanya. Persepsi kegunaan diartikan sebagai suatu persepsi yang dimiliki oleh seseorang bahwa penggunaan suatu teknologi akan meningkatkan performa kinerja dan memberikan manfaat pada seseorang dalam menggunakannya (Syaninditha dan Setiawan, 2017). Dapat disimpulkan bahwa jika wajib pajak merasakan manfaat yang didapatkan dalam menggunakan sistem eSPT, maka wajib pajak akan menggunakan sistem e-SPT, namun jika wajib pajak tidak yakin dan tidak merasakan manfaat dalam menggunakan e-SPT, maka wajib pajak akan merasa ragu untuk menggunakan sistem tersebut.

\section{Kepercayaan}

Sari (2013) mendefinisikan kepercayaan merupakan kepekaaan individu terhadap nilai-nilai yang di bagi antar kedua pihak yang sifatnya menguntungkan bagi kedua pihak. Dalam hal ini 
pihak yang dimaksud adalah KPP dan wajib pajak. Sehingga proses pertukaran nilai-nilai antara Kantor Pelayanan Pajak (KPP) dengan Wajib Pajak (WP) dimana nilai-nilai ini menguntungkan bagi pihak KPP maupun bagi pihak wajib pajak. Sedangkan Chandra (2016) menjelaskan kepercayaan (trust) adalah suatu faktor yang ada pada diri seseorang untuk mendorong dan menyakini hal yang dianggapnya benar untuk dilakukan. Supaya wajib pajak menjalankan, menerapkan dan menggunakan e-SPT untuk pelaporan pajaknya, diperlukan adanya kepercayaan dari wajib pajak terhadap sistem e-SPT.

\section{Computer Self Efficacy}

Self efficacy adalah seseorang yang memiliki keyakinan atas kemampuannya dalam melakukan suatu usaha sehingga dapat mengontrol hasil dari tindakan yang dilakukannya (Chandra, 2016). Computer Self Efficacy (CSE) merupakan penilaian seseorang terhadap kemampuan yang ada dalam dirinya untuk melaksanakan tugas (Irmadhani dan Nugroho, 2012). Dapat disimpulkan bahwa computer self efficacy merupakan penilaian seseorang untuk menilai kemampuannya dalam menggunakan komputer. Computer self efficacy terhadap sistem eSPT dapat diartikan pengguna atau wajib pajak yang meyakini bahwa di dalam dirinya terdapat kemampuan menggunakan suatu komputer untuk melaporkan pajak menggunakan sistem e-SPT.

\section{Minat Penggunaan E-SPT}

Minat menurut Slameto (2010) adalah rasa ketertarikan atau suka pada suatu hal, tanpa adanya paksaan. Dapat disimpulkan bahwa minat merupakan sikap ketertarikan yang dalam diri seseorang untuk melakukan suatu hal dengan perasaan senang tanpa paksaan. Sedangkan minat penggunaan e-SPT menurut Chandra (2016) adalah ketertarikan wajib pajak melakukan pelaporan pajak dengan menggunakan e-SPT dengan rasa senang tanpa adanya suatu paksaan.

E-SPT merupakan aplikasi penyampaian data SPT oleh wajib pajak dalam bentuk elektronik yang dibuat oleh wajib pajak dan juga dapat dilaporkan melalui media elektronik yang dibawa ke KPP (Novindra dan Rasmini, 2017). Menurut Saraswati, Prita dan Kiswara (2013), e-SPT adalah aplikasi yang disediakan oleh dirjen pajak yang dapat digunakan oleh wajib pajak untuk memudahkan penyampaian dan pelaporan SPT. Sedangkan Peraturan Direktur Jenderal Pajak Nomor PER -
01/PJ/2017 menjelaskan SPT Elektronik (E-SPT) adalah SPT yang disampaikan dalam bentuk dokumen elektronik. Dapat disimpulkan bahwa eSPT merupakan aplikasi yang berisi data SPT wajib pajak dalam bentuk dokumen elektronik yang dibuat oleh wajib pajak untuk membantu wajib pajak dalam melaporkan perhitungan dan pembayaran pajak sesuai dengan peraturan perundangundangan yang berlaku.

\section{Pengaruh Persepsi Kegunaan Terhadap Minat} Penggunaan E-SPT

Persepsi kegunaan yang diungkapkan oleh Syaninditha dan Setiawan (2017) diartikan sebagai suatu persepsi yang dimiliki oleh seseorang bahwa penggunaan suatu teknologi akan meningkatkan performa kinerja dan memberikan manfaat pada seseorang dalam menggunakannya. Persepsi kegunaan digunakan untuk melihat sejauh mana eSPT bermanfaat bagi wajib pajak. Jika wajib pajak merasakan adanya manfaat dalam menggunakan sistem e-SPT, maka wajib pajak akan menggunakan sistem e-SPT.

Hasil penelitian terdahulu Novindra dan Rasmini (2017), Syaninditha dan Setiawan (2017), Chandra (2016), Dharma dan Noviari (2016) serta Andrian, Kertahadi dan Susilo (2014) menyebutkan bahwa persepsi kegunaan berpengaruh positif dan signifikan terhadap minat penggunaan suatu esistem. Hal ini dikarenakan persepsi kegunaan mengukur sejauh mana sebuah sistem dapat memberikan manfaat yang positif bagi wajib (Novindra dan Rasmini, 2017). Sehingga seseorang akan merasakan manfaat dari kegunaan suatu teknologi. Semakin bermanfaat e-SPT bagi wajib pajak, maka meningkat pula minat penggunaan e-SPT. Dengan demikian semakin meningkat persepsi kegunaan, maka minat penggunaan e-SPT akan meningkat.

$\mathrm{H}_{1}$ : Persepsi kegunaan berpengaruh positif dan signifikan terhadap minat penggunaan e-SPT.

\section{Pengaruh Kepercayaan Terhadap Minat Penggunaan E- $\underline{S P T}$}

Kepercayaan yang dijelaskan oleh Chandra (2016) adalah suatu faktor yang ada pada diri seseorang untuk mendorong dan menyakini hal yang dianggapnya benar untuk dilakukan. Kepercayaan digunakan untuk mengetahui bagaimana seseorang menjalankan, menerapkan dan menggunakan e-SPT dalam pelaporan pajaknya. Sehingga diperlukan adanya kepercayaan dari wajib pajak terhadap sistem e-SPT. 
Berdasarkan teori TAM yang menjelaskan tentang bagaimana pengguna teknologi informasi mengembangkan teori psikologis berdasarkan pada keinginan, kepercayaan, hubungan perilaku pengguna dan sikap, serta hasil penelitian terdahulu Chandra (2016) menyebutkan bahwa kepercayaan berpengaruh terhadap minat penggunaan e-SPT. Hal ini dikarenakan percaya terhadap suatu hal membuat orang tersebut menerapkan, menggunakan dan menjalankan suatu hal tersebut (Chandra, 2016). Diperlukan suatu kepercayaan dari wajib pajak, agar para wajib pajak menerapkan, menggunakan dan menjalankan sistem e-SPT untuk pelaporan pajaknya. Dengan demikian semakin meningkat kepercayaan maka minat penggunaan e-SPT akan meningkat.

$\mathrm{H}_{2}$ : Kepercayaan berpengaruh positif dan signifikan terhadap minat penggunaan e-SPT.

\section{Pengaruh Computer Self Efficacy Terhadap Minat Penggunaan E-SPT \\ Computer Self Efficacy (CSE) yang didefinisikan} oleh Irmadhani dan Nugroho (2012) merupakan penilaian seseorang terhadap kemampuan yang ada dalam dirinya untuk melaksanakan tugas. Computer self efficacy digunakan untuk melihat sejauh mana pengguna atau wajib pajak meyakini bahwa di dalam dirinya memiliki kemampuan menggunakan suatu komputer untuk melaporkan pajak pada sistem e-SPT.

Hasil penelitian Novindra dan Rasmini (2017) dan Chandra (2016) menemukan adanya pengaruh positif dan signifikan computer self efficacy terhadap minat penggunaan e-SPT. Hal ini dikarenakan apabila seseorang memiliki tingkat kemampuan computer self efficacy tinggi akan berpengaruh pada minat penggunaan teknologi informasi (Novindra dan Rasmini, 2017). Maka seseorang yang memiliki computer self efficacy tinggi akan lebih mudah untuk beradaptasi dengan teknologi yang baru.

$\mathrm{H}_{3}$ : Computer self efficacy berpengaruh positif dan signifikan terhadap minat penggunaan e-SPT.

\section{$\underline{\text { Model Analisis }}$}

Model analisis dalam penelitian ini digambarkan dalam gambar 1:

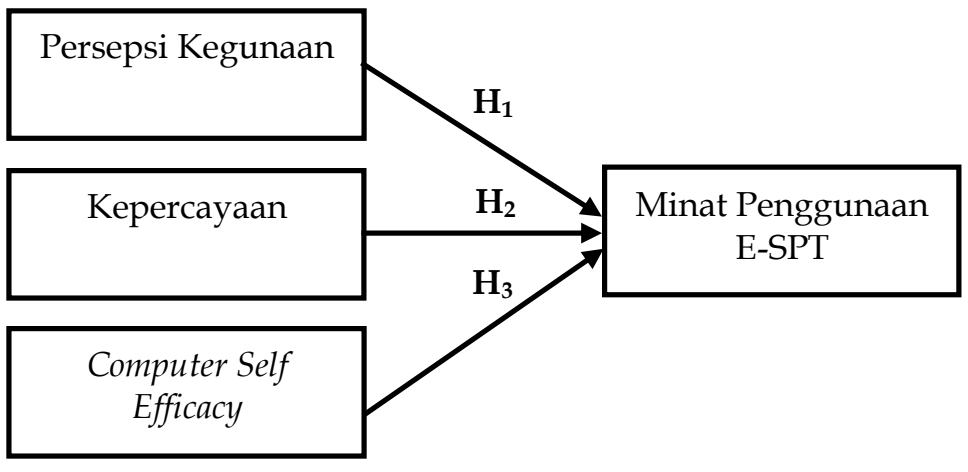

Gambar 1. Model Analisis

\section{METODE PENELITIAN}

Jenis dan Pendekatan Penelitian

Jenis penelitian ini merupakan penelitian kuantitatif yang fokus pada pengujian hipotesis, sehingga dapat menemukan kebenaran dari hipotesis itu sendiri, yang selanjutnya dilakukan uji statistik untuk memberikan informasi dan penjelasan berupa data-data yang akurat agar dapat dianalisis lebih lanjut.Penelitian kuantitatif dalam melihat hubungan variabel terhadap obyek yang diteliti bersifat sebab dan akibat (kausal), sehingga dalam penelitiannya ada variabel independen dan variabel dependen.

\section{Variabel Penelitian}

Variabel independen (bebas) dalam penelitian ini adalah persepsi kegunaan, kepercayaan dan computer self efficacy.Variabel dependen (terikat) dalam penelitian ini adalah minat penggunaan eSPT.

\section{Indikator Variabel Penelitian}

1. Variabel Persepsi Kegunaan $\left(\mathrm{X}_{1}\right)$ :Indikator yang digunakan untuk mengukur variabel persepsi kegunaan diambil dari teori TAM dan penelitian Syaninditha dan Setiawan (2017), yang terdiri dari indikator memberi manfaat dan meningkatkan performa kinerja. Variabel ini akan diukur melalui 6 item pertanyaan. Setiap item pertanyaan diukur dengan menggunakan skala likert mulai dari 1 (sangat tidak setuju), 2 (tidak setuju), 3 (kurang setuju), 4 (setuju) dan 5 (sangat setuju).

2. Variabel Kepercayaan $\left(X_{2}\right)$ :Indikator yang digunakan untuk mengukur variabel kepercayaan diambil dari teori TAM dan penelitian Chandra (2016) yang diukur menggunakan indikator dapat dipercaya, dapat menjaga janji dan komitmen, serta adanya pemikiran untuk mempercayai. Variabel ini 
akan diukur melalui 7 item pertanyaan. Setiap item pertanyaan diukur dengan menggunakan skala likert mulai dari 1 (sangat tidak setuju), 2 (tidak setuju), 3 (kurang setuju), 4 (setuju) dan 5 (sangat setuju).

3. Variabel Computer Self Efficacy $\left(\mathrm{X}_{3}\right)$ :Indikator yang digunakan untuk mengukur variabel computer self efficacy diambil dari teori Irmadhani (2012), yang terdiri dari indikator magnitude, strenght dan general ability. Variabel ini akan diukur melalui 6 item pertanyaan. Setiap item pertanyaan diukur dengan menggunakan skala likert mulai dari 1 (sangat tidak setuju), 2 (tidak setuju), 3 (kurang setuju), 4 (setuju) dan 5 (sangat setuju).

4. Variabel Minat Penggunaan E-SPT (Y) :Indikator yang digunakan untuk mengukur variabel minat penggunaan e-SPT diambil dari Teori TAM dan Chandra (2016), diantaranya keinginan menggunakan, selalu mencoba menggunakan dan berlanjut di masa depan. Variabel ini akan diukur melalui 6 item pertanyaan. Setiap item pertanyaan diukur dengan menggunakan skala likert mulai dari 1 (sangat tidak setuju), 2 (tidak setuju), 3 (kurang setuju), 4 (setuju) dan 5 (sangat setuju).

\section{Lokasi Penelitian}

Penelitian ini dilakukan di Kota Surabaya, dengan menyebar kuesioner online yang dibuat melalui Google Forms untuk memperoleh data minat penggunaan e-SPT wajib pajak orang pribadi.

\section{Populasi, Sampel dan Teknik Pengambilan Sampel}

Populasi dalam penelitian ini adalah wajib pajak orang pribadi yang berdomisili di Surabaya, yang mempunyai NPWP dan menggunakan e-SPT dalam pelaporan pajaknya.Dilihat dari populasi yang akan diteliti, jenis populasi ini merupakan populasi yang jumlahnya tidak diketahui (infinit). Peneliti menyebar kuesioner online melalui Google Forms, maka tidak diketahui jumlah pengguna eSPT secara pasti.Beda halnya jika peneliti melakukan penelitian di Kantor Pelayanan Pajak (KPP) yang datanya sudah diketahui berapa jumlah wajib pajak orang pribadi yang terdaftar menggunakan e-SPT.

Menurut Sugiyono (2016) jumlah sampel yang layak dalam penelitian antara 30 sampai 500. Maka dalam penelitian ini mengambil sempel sebanyak 90 responden wajib pajak orang pribadi di Surabaya. Teknik pengambilan sampel yang digunakan dalam penelitian ini adalah non probability sampling, dengan menggunakan sampling kuota. Kuesioner online telah disebar via media sosial ke wajib pajak orang pribadi melalui laman https://forms.gle/93QN5DVwa2mFNbUQ6, jika telah memenuhi target sebanyak 90 responden atau lebih, maka penelitian ini dipandang selesai, karena telah memenuhi kuota yang ditentukan. Hal tersebut dilakukan untuk mengantisipasi tingkat kesalahan sampel sehingga jumlah sampel layak untuk diteliti.

\section{Metode Pengumpulan Data}

Data penelitian ini adalah data primer. Pengumpulan data dilakukan dengan menggunakan kuesioner online melalui Google Forms. Penyebaran kuesioner dilakukan via media sosial ke wajib pajak orang pribadi melalui laman https://forms.gle/93QN5DVwa2mFNbUQ6. Kuesioner dikirimkan kepada responden yang kebetulan cocok dan bersedia menjadi responden. Selanjutnya responden diharuskan menjawab pertanyaan-pertanyaan yang diajukan oleh peneliti melalui kuesioner online (Google Forms).

\section{Teknik Analisis Data}

Statistik Deskriptif digunakan untuk menjelaskan data yang telah terkumpul dilihat dari nilai minimum, maksimum, rata-rata (mean) dan simpangan baku (standar deviasi). Uji Normalitas digunakan untuk memenuhi syarat asumsi normalitas data. Uji $t$ digunakan untuk membuktikan apakah variabel independen memiliki pengaruh pada variabel dependen secara sendiri-sendiri. Uji R2 digunakan untuk menjelaskan mengenai sejauh mana variabel independen memiliki kemampuan untuk memengaruhi variabel dependen. Analisis Regresi Linier Berganda digunakan untuk mengetahui pengaruh kemudahan penggunaan, persepsi kegunaan dan computer self efficacy.

\section{HASIL DAN PEMBAHASAN}

\section{Statistik Deskripstif}

Berdasarkan tabel 1, menunjukan jumlah responden $(\mathrm{N})$ sebanyak 90 . Maka pembahasan statistik deskriptif pada masing-masing variabel sebagai berikut:

1. Variabel persepsi kegunaan $\left(X_{1}\right)$ mempunyai nilai minimum sebesar 12 dan nilai maksimum sebesar 30. Rata-rata atau mean dari 90 responden sebesar 24,44 dengan standart error sebesar 0,446 dan nilai standart deviasi sebesar 4,232 .

2. Variabel kepercayaan $\left(X_{2}\right)$ mempunyai nilai minimum sebesar 17 dan nilai maksimum 
sebesar 35. Rata-rata atau mean dari 90 responden sebesar 28,33 dengan standart error sebesar 0,528 dan nilai standart deviasi sebesar 5,006 .

3. Variabel computer self efficacy $\left(\mathrm{X}_{3}\right)$ mempunyai nilai minimum sebesar 12 dan nilai maksimum sebesar 24. Rata-rata nilai atau mean dari 90 responden sebesar 19,80 dengan standart error sebesar 0,360 dan nilai standart sebesar 3,412.

4. Variabel minat penggunaan e-SPT (Y) mempunyai nilai minimum sebesar 12 dan nilai maksimum sebesar 30. Rata-rata atau mean dari 90 responden sebesar 22,33 dengan standart error sebesar 0,542 dan nilai standart deviasi sebesar 5,139.

\section{Tabel 1 : Hasil Statistik Deskriptif Variabel}

\begin{tabular}{|l|r|r|r|r|r|r|}
\hline & \multicolumn{1}{|c|}{$\begin{array}{c}\text { Mini- } \\
\text { mum }\end{array}$} & $\begin{array}{c}\text { Maxi- } \\
\text { mum }\end{array}$ & \multicolumn{2}{|c|}{ Mean } & \multicolumn{1}{|c|}{$\begin{array}{c}\text { Std. } \\
\text { Devia- } \\
\text { tion }\end{array}$} \\
\cline { 2 - 7 } & $\begin{array}{c}\text { Statis- } \\
\text { tic }\end{array}$ & Statistic & Statistic & $\begin{array}{c}\text { Statis- } \\
\text { tic }\end{array}$ & $\begin{array}{c}\text { Std. } \\
\text { Er- } \\
\text { ror }\end{array}$ & Statistic \\
\hline $\begin{array}{l}\text { Persepsi } \\
\text { Kegunaan }\end{array}$ & 90 & 12 & 30 & 24.44 & .446 & 4.232 \\
$\begin{array}{l}\text { Ke- } \\
\text { percayaan }\end{array}$ & 90 & 17 & 35 & 28.33 & .528 & 5.006 \\
$\begin{array}{l}\text { CSE } \\
\text { Minat }\end{array}$ & 90 & 12 & 24 & 19.80 & .360 & 3.412 \\
$\begin{array}{l}\text { Penggunaa } \\
\text { n E-SPT }\end{array}$ & 90 & 12 & 30 & 22.33 & .542 & 5.139 \\
$\begin{array}{l}\text { Valid } \\
\text { (listwise) }\end{array}$ & 90 & & & & & \\
\hline
\end{tabular}

\section{Uji Normalitas}

Tabel 2 : Hasil Uji Normalitas

\begin{tabular}{|c|c|c|}
\hline & & $\begin{array}{c}\text { Unstandardized } \\
\text { Residual }\end{array}$ \\
\hline $\mathrm{N}$ & & 90 \\
\hline \multirow{2}{*}{ Normal Parameters $\mathrm{a}, \mathrm{b}$} & Mean & \\
\hline & Std.Deviation & 3.60796707 \\
\hline \multirow{3}{*}{ Most Extreme Differences } & Absolute & .140 \\
\hline & Positive & .080 \\
\hline & Negative & -.140 \\
\hline Kolmogorov-Smirnov Z & & 1.326 \\
\hline Asymp. Sig. (2-tailed) & & .059 \\
\hline
\end{tabular}

Berdasarkan tabel 2, diketahui nilai signifikansi Asymp.Sig.sebesar 0,059. Maka sesuai dengan dasar pengambilan keputusan dalam uji normalitas kolmogrov-smirnov di atas dapat disimpulkan bahwa data berdistribusi normal, karena 0,059 lebih besar dari 0,05. Maka H0 diterima.Sehingga asumsi atau persyaratan normalitas dalam model regresi sudah terpenuhi. $\underline{\text { Ujit }}$

Tabel 3 : Hasil Uji t

\begin{tabular}{|c|c|c|c|c|c|}
\hline \multirow[t]{2}{*}{ Model } & \multicolumn{2}{|c|}{$\begin{array}{c}\text { Unstandardized } \\
\text { Coefficients }\end{array}$} & \multirow{2}{*}{$\begin{array}{l}\text { Standard- } \\
\text { ized Coeffi- } \\
\text { cients } \\
\text { Beta }\end{array}$} & \multirow[t]{2}{*}{$\mathrm{t}$} & \multirow[t]{2}{*}{ Sig. } \\
\hline & B & $\begin{array}{l}\text { Std. } \\
\text { Error }\end{array}$ & & & \\
\hline (Constant) & -7.900 & 3.777 & & -2.092 & .039 \\
\hline Persepsi & .275 & .092 & .227 & 2.981 & .004 \\
\hline $1_{1}^{\text {Kegunaan }}$ & & & & & \\
\hline Kepercayaan & .656 & .078 & .639 & 8.404 & .000 \\
\hline CSE & .248 & .114 & .165 & 2.175 & .032 \\
\hline
\end{tabular}

Berdasarkan tabel 3, diketahui variabel persepsi kegunaan memiliki nilai signifikan sebesar 0,004, variabel kepercayaan memiliki nilai signifikan sebesar 0,000 dan variabel computer self efficacy memiliki nilai signifikan sebesar 0,032. Maka ketiga variabel tersebut memiliki nilai signifikan kurang dari 0,05, artinya ketiganya berpengaruh secara parsial atau sendiri-sendiri terhadap variabel minat penggunaan e-SPT. Sehingga dapat disimpulkan bahwa persepsi kegunaan berpengaruh signifikan terhadap minat penggunaan e-SPT, kepercayaan berpengaruh signifikan terhadap minat penggunaan e-SPT dan computer self efficacyberpengaruh signifikan terhadap minat penggunaan eSPT.

\section{$\underline{U j i R 2}$}

\begin{tabular}{|l|l|r|r|r|}
\multicolumn{7}{|c|}{ Tabel 4 : Hasil Uji R2 } \\
\hline Model & $\mathrm{R}$ & R Square & $\begin{array}{c}\text { Adjusted R } \\
\text { Square }\end{array}$ & $\begin{array}{c}\text { Std. Error of } \\
\text { the Estimate }\end{array}$ \\
\hline 1 & $.712^{\mathrm{a}}$ & .507 & .490 & 3.670 \\
\hline
\end{tabular}

Berdasarkan tabel 4, menunjukan bahwa hasil uji R2 diperoleh nilai Adjusted R Square sebesar 0,490 yang berarti bahwa persepsi kegunaan, kepercayaan dan computer self efficacy berpengaruh sebesar $49 \%$ terhadap minat penggunaan e-SPT. Sedangkan $51 \%$ dipengaruhi variabel lain yang tidak diteliti.

\section{Analisis Regresi Linier Berganda}


Tabel 5 :Analisis Regresi Linier Berganda

\begin{tabular}{|l|r|r|r|r|r|}
\hline \multirow{2}{*}{ Model } & \multicolumn{2}{|c|}{$\begin{array}{r}\text { Unstandardized } \\
\text { Coefficients }\end{array}$} & $\begin{array}{r}\text { Standard- } \\
\text { ized Coeffi- } \\
\text { cients }\end{array}$ & Sig. \\
\cline { 2 - 4 } & \multicolumn{1}{|c|}{$\mathrm{B}$} & \multicolumn{1}{|c|}{ Std. } & \multicolumn{1}{|c|}{ Beta } & & \\
\cline { 2 - 3 } (Constant) & -7.900 & 3.777 & & -2.092 & .039 \\
Persepsi Kegunaan & .275 & .092 & .227 & 2.981 & .004 \\
1 Kepercayaan & .656 & .078 & .639 & 8.404 & .000 \\
CSE & .248 & .114 & .165 & 2.175 & .032 \\
\hline
\end{tabular}

Berdasarkan tabel 5, maka dihasilkan persamaan regresi sebagai berikut: $Y=\alpha+\beta 1 . X 1+\beta 2 . X 2+$ $\beta 3 . X 3+$ e :Y $=-7,900+0,275 . X 1+0,656 . X 2+$ $0,248 . X 3+\mathrm{e}$

Hasil persamaan regresi linier berganda tersebut, memberikan pengertian sebagai berikut::

1. Nilai konstanta (a) sebesar $-7,900$, menunjukan bahwa jika nilai persepsi kegunaan, kepercayaan dan computer self efficacy sama dengan 0 (nol), maka nilai dari minat penggunaan e-SPT menurun sebesar 7,900 satuan.

2. Nilai $\beta 1$ (koefisien regresi variabel persepsi kegunaan) sebesar 0,275, menunjukan bahwa jika nilai persepsi kegunaan bertambah satu satuan, maka nilai dari minat penggunaan e-SPT akan meningkat sebesar 0,275 satuan.

3. Nilai $\beta 2$ (koefisien regresi variabel kepercayaan) sebesar 0,656, menunjukan bahwa jika nilai kepercayaan bertambah satu satuan, maka nilai dari minat penggunaan e-SPT akan meningkat sebesar 0,656 satuan.

4. Nilai $\beta 3$ (koefisien regresi variabel computer self efficacy) sebesar 0,248, menunjukan bahwa jika nilai computer self efficacy bertambah satu satuan, maka nilai dari minat penggunaan e-SPT akan meningkat sebesar 0,248 satuan.

\section{Pembahasan}

Berdasarkan hasil uji analisis data di atas, maka dapat diuraikan bahwa persepsi kegunaan mempunyai pengaruh yang signifikan terhadap minat penggunaan e-SPT. Hal ini dibuktikan melalui uji $\mathrm{t}$ menghasilkan nilai signifikan sebesar 0,004 lebih kecil dari 0,05. Dan berdasarkan hasil analisis regresi linier berganda mempunyai nilai positif sebesar 0,275. Sehingga dapat disimpulkan bahwa variabel persepsi kegunaan berpengaruh positif dan signifikan terhadap minat penggunaan e-SPT. Hasil penelitian ini telah membuktikan berdasarkan teori TAM, bagaimana pengguna teknologi dapat menggunakan dan menerima teknologi dalam pekerjaannya. Dan hasil penelitian ini memiliki kesamaan dengan hasil penelitian Novindra dan Rasmini (2017), Syaninditha dan Setiawan (2017), Chandra (2016), Dharma dan Noviari (2016) dan Andrian, Kerta-hadi dan Susilo (2014) yang menunjukan adanya pengaruh positif dan signifikan persepsi kegunaan terhadap minat penggunaan suatu sistem. Hal ini dikarenakan persepsi kegunaan melihat sejauh mana sebuah sistem dapat memberikan kontribusi manfaat yang positif bagi penggunanya (Novindra dan Rasmini, 2017). Sehingga seseorang akan merasakan manfaat dari kegunaan suatu teknologi. Semakin bermanfaat eSPT bagi wajib pajak, maka minat penggunaan eSPT akan meningkat. Dengan demikian semakin meningkat persepsi kegunaan, maka minat penggunaan e-SPT akan meningkat . Selain itu hasil penelitian ini bertolak belakang dengan penelitian Rakhmawati (2013) yang menunjukan bahwa persepsi kegunaan tidak berpengaruh positif dan signifikan terhadap minat penggunaan suatu sistem. Hal ini dikarenakan pengguna merasa tidak yakin apabila menggunakan suatu sistem akan mendatangkan manfaat, maka pengguna akan merasa ragu untuk menggunakan sistem tersebut (Novindra dan Rasmini, 2017).

Kepercayaan mempunyai pengaruh yang signifikan terhadap minat penggunaan e-SPT. Hal ini dibuktikan melalui uji $\mathrm{t}$ menghasilkan nilai signifikan sebesar 0,000 lebih kecil dari 0,05. Dan berdasarkan hasil analisis regresi linier berganda mempunyai nilai positif sebesar 0,656 . Sehingga dapat disimpulkan variabel kepercayaan berpengaruh positif dan signifikan terhadap minat penggunaan e-SPT. Hasil penelitian ini telah membuktikan berdasarkan teori TAM, bagaimana pengguna teknologi dapat menggunakan dan menerima teknologi yang dikembangkan dari teori psikologis berdasarkan kepercayaan (trust) dalam pekerjaannya. Hasil ini memiliki kesamaan dengan hasil penelitian Chandra (2016) yang menunjukan adanya pengaruh positif dan signifikan kepercayaan terhadap minat penggunaan e-SPT. Hal ini dikarenakan percaya terhadap sesuatu membuat seseorang menjalankan, menerapkan dan menggunakan sesuatu tersebut (Chandra, 2016). Maka diperlukan suatu kepercayaan dari wajib pajak, agar para wajib pajak menjalankan, men- 
erapkan dan menggunakan sistem e-SPT untuk pelaporan pajaknya. Dengan demikian semakin meningkat kepercayaan maka minat menggunakan e-SPT akan meningkat.

Computer self efficacy mempunyai pengaruh yang signifikan terhadap minat penggunaan e-SPT. Hal ini dibuktikan melalui uji $\mathrm{t}$ menghasilkan nilai signifikan sebesar 0,032 lebih kecil dari 0,05. Dan berdasarkan hasil analisis regresi linier berganda mempunyai nilai positif sebesar 0,248 . Sehingga dapat disimpulkan bahwa variabel computer self efficacy berpengaruh positif dan signifikan terhadap minat penggunaan e-SPT. Hasil penelitian ini telah membuktikan berdasarkan teori TAM, bagaimana pengguna teknologi dapat menggunakan dan menerima teknologi dalam pekerjaannya. Hasil penelitian ini memiliki kesamaan dengan hasil penelitian Novindra dan Rasmini (2017) dan Chandra (2016) yang menunjukan adanya pengaruh positif dan signifikan computer self efficacy terhadap minat penggunaan e-SPT. Hal ini dikarenakan apabila seseorang memiliki tingkat kemampuan computer self efficacy tinggi akan berpengaruh pada minat penggunaan teknologi informasi (Novindra dan Rasmini, 2017). Sehingga seseorang yang memiliki computer self efficacy tinggi akan lebih mudah untuk beradaptasi dengan teknologi yang baru. Dengan demikian semakin meningkat computer self efficacy maka minat penggunaan e-SPT akan meningkat. Selain itu hasil penelitian ini bertolak belakang dengan penelitian (Setyowati dan Respati, 2017) yang menunjukan bahwa computer self efficacy tidak berpengaruh signifikan terhadap minat penggunaan suatu sistem. Hal ini dikarenakan kesiapan teknologi pada dasarnya dipengaruhi oleh individu itu sendiri, apakah dari dalam diri individu siap menerima teknologi (Risky, 2015). Jika suatu sistem tidak dapat diterima oleh seseorang yang tidak mempunyai keahlian dalam komputer, maka orang tersebut akan enggan untuk menggunakannnya.

\section{SIMPULAN}

Berdasarkan analisis yang telah dilakukan, dapat ditarik kesimpulan bahwa persepsi kegunaan berpengaruh positif dan signifikan terhadap minat penggunaan e-SPT. Hal ini berarti seseorang akan merasakan manfaat dari kegunaan suatu teknologi. Semakin bermanfaat e-SPT bagi wajib pajak, maka minat penggunaan e-SPT akan meningkat. Kepercayaan berpengaruh positif dan signifikan terhadap minat penggunaan e-SPT. Hal ini berarti semakin meningkat kepercayaan wajib pajak terhadap e-SPT, maka minat penggunaan e-
SPT akan meningkat. Computer self efficacy berpengaruh positif dan signifikan terhadap minat penggunaan e-SPT. Hal ini berarti bahwa semakin meningkat computer self efficacy wajib pajak, maka minat penggunaan e-SPT akan meningkat.

Adapun keterbatasan dalam penelitian ini yaitu, variabel persepsi kegunaan, kepercayaan dan computer self efficacy memberikan sumbangan $49 \%$ terhadap minat penggunaan e-SPT, sedangkan sisanya $51 \%$ dijelaskan faktor lain yang tidak diteliti dalam penelitian ini. Berdasarkan hasil tersebut diharapkan dalam penelitian mendatang dapat menambahkan variabel lainnya yang dapat berpengaruh terhadap minat penggunaan e-SPT, seperti kepuasan dan keamanan.

Selain itu ada beberapa saran yang diberikan bagi peneliti selanjutnya dan bagi Kantor Pelayanan Pajak (KPP) yaitu, bagi peneliti selanjutnya supaya memperluas cakupan responden baik dari cakupan wilayah maupun jenis wajib pajak. Pada penelitian ini memberikan suatu informasi bahwa dalam variabel computer self efficacy memiliki nilai mean terendah sebesar 3,08 yang terdapat pada item pertanyaan ketiga dan keempat, yaitu wajib pajak masih membutuhkan bantuan atau pertolongan seseorang dan masih membutuhkan panduan manual saat menemui kesulitan ketika membuat laporan pajak melalui sistem e-SPT. Berdasarkan hal tersebut disarankan kepada Kantor Pelayanan Pajak (KPP) untuk sering mengadakan sosialisasi, menyediakan panduan secara manual maupun online yang mudah dipahami oleh wajib pajak, meng-update hal-hal baru berkaitan dengan penggunaan sistem e-SPT dan memberikan layanan bantuan saat wajib pajak menghadapi kesulitan dalam pengisian laporan pajak.

\section{REFERENCES}

Andrian, A., Kertahadi dan Susilo, H. (2014). Analisis Pengaruh Persepsi Kegunaan, Persepsi Kemudahan, dan Sikap Penggunaan Terhadap Minat Perilaku Penggunaan Billing System. Jurnal Perpajakan Universitas Brawijaya, 3(1), 1-10.

Chandra, I. R. (2016).Pengaruh Kemudahan Penggunaan, Kepercayaan, dan Computer Self Efficacy Terhadap Minat Penggunaan E-SPT dalam Pelaporan Pajak. Jurnal Nominal, 5(1), 72-87.

Desmayanti, E. (2012). Faktor-Faktor Yang Mempengaruhi Penggunaan Fasilitas EFilling Oleh Wajib Pajak Sebagai Sarana Penyampaian SPT Masa Secara Online dan Realtime.(Skripsi, Fakultas Ekonomika dan 
Bisnis Universitas Diponegoro).

Dharma, I W. M. H. dan Noviari, N. (2016).FaktorFaktor yang Berpengaruh Pada Intensitas Perilaku Dalam Penggunaan E-Filing Oleh Wajib Pajakorang Pribadi.E-Jurnal Akuntansi Universitas Udayana, 17(2), 1342-1370.

Irmadhani dan Nugroho, M. A. (2012). Pengaruh Persepsi Kebermanfaatan, Persepsi Kemudahan Penggunaan dan Computer Self Efficacy Terhadap Penggunaan Online Banking pada Mahasiswa S1 Fakultas Ekonomi Universitas Negeri Yogyakarta. Jurnal Akuntansi UNY, 1(3),1-20.

Novindra, N. P. B. dan Rasmini, N. K. (2017). Pengaruh Kemudahan Penggunaan, Persepsi Kegunaan, dan Computer Self EfficacyPada Minat Penggunaan E-SPT. E-Jurnal Akuntansi Universitas Udayana, 19(2), 11161143.

Peraturan Direktur Jenderal Pajak Nomor PER 01/PJ/2017 Tentang Penyampaian Surat Pemberitahuan Elektronik.

Rachmawati, A. N. (2018, Maret 12).Padahal Lebih Cepat, Jumlah Pelaporan SPT Melalui eFilling di Surabaya Masih Terbilang Rendah.Didapat dari Jatim Tribun News: http://jatim.tribunnews.com/2018/03/12 / padahal-lebih-cepat-jumlah-pelaporanspt-melalui-e-filling-di-surabaya-masihterbilang-rendah, 21 Maret 2019, pukul 18.55 WIB.

Rakhmawati, S. (2013). Pengaruh Kepercayaan, Persepsi Kegunaan, Persepsi Kemudahan, dan Persepsi Kenyamanan Terhadap Minat Penggunaan Sistem Internet Banking Pada Nasabah Bank Muamalat Cabang Pembantu Madiun. Jurnal Akuntansi dan Pendidikan, 2(2), 71-84.

Risky, D. (2015). Analisis faktor-faktor yang mempengaruhi intensitas perilaku dalam penggunaan sistem e-filling (Studi Kasus Atas Penyampaian Surat Pemberitahuan Pada Pendidik Dan Tenaga Kependidikan Di Fakultas Ilmu Administrasi Universitas Brawijaya).Jurnal Mahasiswa Perpajakan, 6(1).

Saksama, H. Y. (2018). Kepatuhan Meningkat, Penyampaian SPT Tumbuh Double Digit. Dikutip $21 \quad$ Maret 2019 dari http://www.pajak.go.id/kepatuhanmeningkat-penyampaian-spt-tumbuhdouble-digit.

Saraswati, P. dan Kiswara, E. (2013). Analisis Terhadap Penerapan Theory Of Consumer Ac- ceptance Technology Pada E-Spt. Diponegoro Journal of Accounting,2(2), 1-14.

Sari, R. (2013). Pengaruh Persepsi Kebermanfaatan, Kepercayaan, dan Computer Self Efficacy Terhadap Minat Penggunaan E-Banking Pada Mahasiswa S1 Fakultas Ekonomi Universitas Negeri Yogyakarta. (Skripsi, Fakultas Ekonomi Universitas Negeri Yogyakarta).

Setyowati, E. O. T. dan Respati, A. D..(2017). Persepsi Kemudahan Penggunaan, Persepsi Manfaat, Computer Self Efficacy dan Kepuasan Pengguna Sistem Informasi Akuntansi. Jurnal Riset Akuntansi dan Keuangan Fakultas Bisnis UKDW, 13(1), 63-75.

Situmorang, R. (2016). Hubungan Persepsi Kebermanfaatan, Persepsi Kemudahan, Persepsi Kepuasan, Persepsi Kerumitan, Persepsi Resiko Wajib Pajak Orang Pribadi Dengan Penggunaan E-Filing (Studi Kasus Pada Pegawai di Kantor Cabang BRI Cik Ditiro Yogyakarta). (Skripsi, Fakultas Ekonomi Universitas Sanata Dharma Yogyakarta).

Slameto.(2010). Belajar dan Faktor-faktor yang Mempengauhinya. Jakarta: PT. Rineka Cipta.

Sugiyono. (2016). Metode Penelitian Kuantitatif, Kualitatif, dan RED. Bandung: Alfabeta, CV.

Syaninditha, S. A. P. dan Setiawan, P. E. (2017).Pengaruh Persepsi Kegunaan, Persepsi Kemudahan, Faktor Sosial, dan Kondisi yang Memfasilitasi Terhadap Minat Penggunaan E-Filing.E-Jurnal Akuntansi Universitas Udayana, 21(1), 86-115. 